\title{
Presidential Power to "Un-sign" Treaties
}

\author{
David C. Scott $\dagger$
}

Recently, President Bush expressed the desire to "escape permanently" from the Comprehensive Test Ban Treaty ("CTBT"), an international agreement prohibiting all testing of nuclear weapons. ${ }^{2}$ The President wanted to withdraw the treaty from the Senate but the State Department's legal office advised that a president lacks the power to proceed unilaterally. ${ }^{3}$ The CTBT remains pending in the Senate, along with numerous other treaties. ${ }^{4}$

President Clinton signed the CTBT on September 25, 1996. At the time of President Clinton's and the United Nations's endorsement of the treaty, commentators noted the significance of a treaty signature in international law: "[T]he Vienna Convention provides that between the time of signing and ratifying, a state has a legal obligation not to act in a manner inconsistent with the agreement." Getting the

\section{$\dagger$ B.A. 1999, Miami University; J.D. Candidate 2003, The University of Chicago.}

1 Comprehensive Nuclear Test Ban Treaty, S Treaty Doc No 105-28, 105th Cong, 1st Sess (1996), 35 ILM 1439 (1996).

2 See Thom Shanker and David E. Sanger, White House Wants to Bury Pact Banning Tests of Nuclear Arms, NY Times A1 (July 7, 2001) ("[T] he Bush administration has been examining ways to escape permanently from an unratified international agreement banning nuclear tests.").

3 See id ("State Department lawyers told the White House that a president cannot withdraw a treaty from the Senate once it has been presented for approval."). See also Treaties and Other International Agreements: The Role of the United States Senate, S Rep No 106-71, 106th Cong, 2d Sess 145 (2001) ("The President does not have the formal authority to withdraw a treaty from Senate consideration without the Senate's concurrence."); Michael J. Glennon, Constitutional Diplomacy 175 (Princeton 1990) ("[C]ustom apparently supports a requirement that the President seek Senate consent for the withdrawal of a disfavored treaty.").

4 See David D. Newsom, The Senate's Distaste for Treaties-A Perennial Problem for US Diplomacy, Christian Sci Mon 19 (Jan 14, 1998) (noting that several important treaties have languished in the Senate and stating, "Whether or not senators realize it, the US is bound under international law to respect any agreement signed by US negotiators"). See also Pending Treaties, Senate Foreign Relations Committee, available online at <http://foreign.senate.gov/briefing/ treaties.pdf (visited Apr 19, 2002) (providing an updated list of pending treaties that includes the CTBT).

5 See Alison Mitchell, Clinton, at U.N., Signs Treaty Banning All Nuclear Testing, NY Times A1 (Sept 25, 1996) (describing President Clinton's visit to the United Nations, his speech there, and the signing of the CTBT).

6 See Barbara Crossette, U.N. Endorses a Treaty to Halt All Nuclear Testing, NY Times A3 (Sep 11, 1996) (quoting Thomas Franck of New York University Law School). Professor Franck refers to Article 18 of the Vienna Convention on the Law of Treaties, which requires a nation that has signed a treaty to refrain from acting in a way that would defeat the object and purpose of the treaty during the period between signing and ratification. See Part I.B below for a discussion of Article 18. 
CTBT ratified became one of Clinton's top foreign policy goals.' In the face of strong Republican opposition, the President sought to delay a vote in an effort to avoid rejection. ${ }^{8}$ But his efforts to strike a compromise failed, and the treaty came to a vote.' On October 13 , 1999 , the Senate rejected the CTBT by a vote of fifty-one to fortyeight. $^{10}$

Following the defeat, the Clinton administration adopted the argument that the Vienna Convention on the Law of Treaties" imposes obligations on a signatory not to defeat the object and purpose of a signed treaty. ${ }^{12}$ Secretary of State Albright wrote to "foreign governments to say the United States is legally bound to observe the nuclear test-ban treaty, despite the Senate's rejection of the pact." ${ }^{13}$ Thus, although President Clinton could not ratify the treaty without Senate consent, his administration asserted that because the United States had signed the CTBT, it could not act in such a way that would defeat the object and purpose of the treaty. This position is especially significant in the context of a treaty, such as the CTBT, that prohibits the testing of weapons. Under Article 18 the U.S. would be obligated to refrain from testing any nuclear weapons while the signed treaty remained pending." While a signed, but unratified, treaty cannot fully

7 See Marc Lacey, Clinton Kicks Off Campaign to Pass Nuclear Test Ban, NY Times A1 (Oct 5, 1999) (describing President Clinton's efforts to push the treaty through the Senate).

8 See John M. Broder, President Asking Senate to Delay Vote on Test Ban, NY Times A1 (Oct 9,1999) ("Acknowledging that he lacks the votes to approve a treaty banning nuclear testing, President Clinton pleaded with Senate leaders today to delay action.").

9 See 141 Sen Exec J 479 (1999) ("On request by Mr. Helms and with a sufficient second, the yeas and nays were ordered on the Comprehensive Nuclear Test Ban Treaty.").

10 See id ("The vote resulted in yeas 48, nays 51, present 1."); Eric Schmitt, Defeat of a Treaty: The Overview; Senate Kills Test Ban Treaty in Crushing Loss for Clinton; Evokes Versailles Pact Defeat, NY Times A1 (Oct 14, 1999) (reporting on the Senate's vote to decline advice and consent to the CTBT); Helen Dewar, Senate Rejects Test Ban Treaty; Nuclear Pact Falls 51 to 48 as GOP Deals Clinton Major Defeat, Wash Post A1 (Oct 14, 1999) (same). The CTBT became only the twenty-first treaty rejected by a Senate vote. See The World; Doomed Treaties, NY Times Sec 4, 4 (Oct 17,1999) (listing treaties rejected by the Senate).

11 Vienna Convention on the Law of Treaties, S Exec Doc L, 92-1 (1971), 8 ILM 679 (1969) ("Vienna Convention").

12 See Bill Gertz, Albright Says U.S. Bound by Nuke Pact; Sends Letters to Nations Despite Senate Vote, Wash Times A1 (Nov 2, 1999) ("The administration believes it is still bound to legally abide by the test-ban treaty because it has not given up on ratification in the future."). See also John R. Bolton, Should We Take Global Governance Seriously?, 1 Chi J Intl L 205, 212 (2000) (describing the Clinton administration's reliance on Article 18 in order to continue its unilateral policy against nuclear testing); John R. Bolton, Unsign That Treaty, Wash Post A21 (Jan 4,2001 ) ("After the Senate defeated the [CTBT], the administration cited Article 18 ... to justify a continued moratorium on underground nuclear testing.").

13 See Gertz, Albright Says U.S. Bound, Wash Times at A1 (cited in note 12).

14 See Restatement (Third) of the Foreign Relations Law of the United States § 312, comment i (ALI 1987) ("Testing a weapon in contravention of a clause prohibiting such a test might violate the purpose of the agreement, since the consequences of the test might be irreversible."). See also Glennon, Constitutional Diplomacy at $174 \mathrm{n} 61$ (cited in note 3) (noting that the Restatement suggests the test "is whether the consequences of the action in question 'might be irre- 
bind the U.S., ${ }^{15}$ under these circumstances the difference between the international law obligation attendant to signature and the full effect of ratification remains unclear.

President Bush failed in his effort to "escape permanently" from the CTBT by withdrawing it from the Senate. If the President could withdraw the treaty from the Senate, he could "un-sign" it and negate the international law obligation. However, the State Department's legal office and other authorities have concluded that a president may not withdraw a signed treaty from the Senate without consent. ${ }^{16}$

This Comment addresses the question whether a president has the authority to withdraw a signed treaty from the Senate unilaterally in order to negate the consequences of a signature. Part I introduces the treaty-making process and the international law obligation attendant to signature under Article 18 of the Vienna Convention. Part II examines constitutional issues-including textual, structural, and functional arguments. Part III analyzes the historical practice of treaty withdrawal under the Constitution. Part IV discusses international law considerations and the implications of Article 18. Finally, the Comment concludes that both constitutional and international law support a president's power to withdraw a signed treaty unilaterally in order to "un-sign" it.

\section{TREATY PROCESS AND ARTICLE 18}

\section{A. The Treaty-Making Process: Current Practice}

The Constitution provides: "He [the President] shall have Power, by and with the Advice and Consent of the Senate, to make Treaties, provided two thirds of the Senators present concur." As suggested by this language, the process of making treaties involves a series of steps. These steps include negotiation and signing, consideration for advice and consent, and final ratification. ${ }^{18}$ These major steps in the process roughly correspond to either presidential or senatorial action. In modern practice, the President's and Senate's roles in making treaties have become fairly distinct. ${ }^{19}$

versible"').

15 See note 28 and accompanying text.

16 See note 3.

17 US Const Art II, § 2, cl 2. For an examination of the textual implications of this language see Part II.A below.

18 See S Rep No 106-71 at 6-7 (cited in note 3) (describing the steps in the treaty-making process).

19 However, the roles of the President and Senate have not always been so distinct. For a general discussion, see Ralston Hayden, The Senate and Treaties 1789-1817 (MacMillan 1920) (describing the development of the Senate's role in treaty-making during the first twenty-five years under the Constitution). For a thorough treatment of the treaty-making process prior to and under the Articles of Confederation, as well as during the Framing of and early practice un- 
1. Negotiation and signing.

The word "advice" in the Treaty Clause suggests that the President and Senate negotiate treaties together. In fact, this was probably the Framers' intent. ${ }^{20}$ However, practice quickly showed that a shared role was impractical. ${ }^{21}$ President Washington himself found negotiating with the Senate to be difficult and frustrating. ${ }^{2}$ As a result, in modern practice, the President negotiates treaties without the Senate. ${ }^{23}$ Even the Senate endorses this view: "the actual negotiation of treaties and other international agreements is widely recognized as being within the power of the President." ${ }^{24}$

Furthermore, the President, as in the case of the CTBT, ${ }^{25}$ or his representative, also signs or concludes a treaty. ${ }^{26}$ As suggested above, the act of signing a treaty invokes an obligation under international law. ${ }^{27}$ However, a signature does not finalize the process and fully bind a nation under the treaty, as was once the case. ${ }^{23}$ Instead, by signing a

der the Constitution, see Samuel B. Crandall, Treaties, Their Making and Enforcement 19-26 (Columbia 1905).

20 See Louis Henkin, Foreign Affairs and the United States Constitution 177 (Clarendon 2d ed 1996) ("As originally conceived, no doubt, the Senate was to be a kind of Presidential council, affording him advice throughout the treaty-making process and on all aspects of it-whether to enter negotiations, who shall represent the United States, what should be the scope of negotiations, the positions to be taken, the responses to be made, the terms to be accepted."). See also id at 443-44 n 4, 445 $n 7$ (providing several authorities discussing the Senate's intended role).

21 See id at 177 ("Almost from the beginning, however, Presidents found that conception of the Senate's function uncongenial, perhaps unworkable; the Senate, for its part, also rejected it, seeking to deliberate and pass judgment later and independently, rather than to advise.").

22 Recounting Washington's embarrassing visit to the Senate to obtain advice on a treaty, Professor Corwin writes: "The somber truth is that the conception of the Senate as a presidential council in the diplomatic field broke down the first time it was put to the test." Edward S. Corwin, The President: Office and Powers, 1787-1984 239-40 (New York 5th ed 1984).

23 See United States v Curtiss-Wright Export Corp, 299 US 304, 319 (1936) ("[H]e alone negotiates [treaties]."); Henkin, Foreign Affairs at 177 (cited in note 20) ("The Senate does not formally advise on treaties before or during negotiations."); Corwin, The President at 241-42 (cited in note 22) ("So far as practice and weight of opinion can settle the meaning of the Constitution, it is today established that the President alone has the power to negotiate treaties with foreign governments [and] that he is free to ignore any advice tendered him by the Senate as to a negotiation."). However, while it is recognized that the President negotiates, he may involve the Senate through informal consultation or by including the senators in negotiating delegations. See Henkin, Foreign Affairs at 178 (cited in note 20) ("Presidents have developed informal substitutes."). This practice probably results from an interest in obtaining Senate consent and not from any constitutional obligations.

24 S Rep No 106-71 at 97 (cited in note 3).

25 See Mitchell, Clinton, at U.N., NY Times at A1 (cited in note 5) (recognizing that President Clinton negotiated and signed the CTBT).

26 See S Rep No 106-71 at 111 (cited in note 3) ("Like the negotiation, the conclusion or signing is done by the President or his representatives and is considered a function of the executive branch.").

- 27 See notes 12-15 and accompanying text.

28 See Martin A. Rogoff, The International Legal Obligations of Signatories to an Unratified Treaty, 32 Maine L Rev 263, 266-67 (1980) ("While at one time signature played a more impor- 
treaty the President merely signals the United States's consent to be bound upon the further act of ratification. ${ }^{29}$ And this consent to be bound invokes the obligation to refrain from acts that defeat the object and purpose of the treaty. ${ }^{30}$ But, before the President may ratify the signed treaty, he must first obtain Senate consent.

\section{Senate consideration.}

Following conclusion of the treaty, the President usually, though not always, ${ }^{31}$ submits the document to the Senate to obtain advice and consent. Submission involves the President sending a message to the Senate "consisting of the official title and text of the treaty ... and a letter of transmittal, signed by the President, requesting Senate advice and consent.", The president also includes a detailed description and analysis of the treaty provided by the Secretary of State. ${ }^{33}$

Upon receipt of a treaty, Senate and Committee Rules govern consideration. First, the treaty "shall be read a first time," in accordance with Senate Rule XXX, and the Senate refers the treaty to the Committee on Foreign Relations, ${ }^{35}$ in accordance with the jurisdiction of standing committees set forth in Rule $\mathrm{XXV}^{36}$ The Committee places the treaty on the calendar, where it remains until the Committee takes action. ${ }^{37}$ Committee action consists of either reporting the treaty to the

tant role in the process whereby a state assumed treaty obligations, today the crucial event is ratification.").

29 See id; Anthony Aust, Modern Treaty Law and Practice 75-99 (Cambridge 2000) (discussing the different meanings of signature and ratification). Ratification is discussed in Part I.A.3.

30 The discussion of Article 18 in Part I.B expands on this idea.

31 See, for example, Steven Lee Myers, U.S. Signs Treaty for World Court to Try Atrocities, NY Times A1 (Jan 1,2001) ("Mr. Clinton took the unusual step of saying that he would neither submit the treaty for Senate approval nor recommend that his successor do so immediately."). See also S Rep No 106-71 at 118 (cited in note 3) ("Occasionally an administration may decide not to submit a treaty that it or a previous administration had signed."). If the President fails to submit the signed treaty, then he does not face the potential hurdle of withdrawing it from the Senate. However, presidents rarely withhold signed treaties. See id (noting that "occasionally" presidents withhold); Royden J. Dangerfield, In Defense of the Senate: A Study in Treaty Making 328-49 (Kennikat 1966) (listing both treaties signed and submitted and those signed but not submitted prior to 1928 , and showing the former far exceed the latter).

32 S Rep No 106-71 at 118 (cited in note 3).

33 See id (describing the process of Senate receipt of a treaty).

34 Rule XXX(1)(a), Standing Rules of the Senate, S Doc No 106-15, 106th Cong, 2d Sess 39 (2000), available online at $<\mathrm{http}: / /$ rules.senate.gov/senaterules/menu.htm $>$ (visited Apr 18, 2002) (defining procedures on treaties).

35 See id (requiring that the treaty be read once upon receipt, and limiting initial motions on the treaty to referral to a committee, printing, or removal of the injunction of secrecy).

36 See Rule XXV(1)(j)(1)(17), S Doc No 106-15 at 21-22 (cited in note 34) (providing that all matters relating to treaties shall be referred to the Committee on Foreign Relations).

37 See Rule 9(b), Authority and Rules of Senate Committees, Committee on Foreign Relations, S Doc No 106-6, 106th Cong, 1st Sess 99 (1999-2000), available online at <http:// www.access.gpo.gov/congress/senate/srules11.html> (visited Apr 18, 2002) ("[E]ach treaty is re- 
Senate or recommending its return to the President. ${ }^{38}$ If the Committee fails to take action, a treaty might remain on the calendar for years or even decades. Though the Committee is not bound to do so, it usually holds public hearings on the treaty. ${ }^{40}$

When the Committee decides to recommend a treaty, it reports favorably to the Senate in one of the following ways: (1) approval without change, (2) approval with conditions not altering the text, (3) approval if the text is amended, or (4) a combination of the last two possibilities." Reporting a treaty to the Senate involves proposing a resolution of ratification, ${ }^{42}$ which incorporates any conditions recommended by the Committee. ${ }^{43}$ After this step, consideration of the treaty shifts to the entire Senate.

Under Senate Rule XXX, in considering a treaty reported from the Committee the Senate proposes amendments ${ }^{45}$ and incorporates its decisions into the resolution of ratification. ${ }^{45}$ The Senate then considers the resolution itself, and may amend it "in the form of reservations, declarations, statements, or understandings." ${ }^{\prime 47}$ Consideration concludes with a vote on the resolution of ratification, requiring two-

ferred to the Committee and remains on its calendar from Congress to Congress until the Committee takes action to report it to the Senate or recommend its return to the President."); $\mathrm{S}$ Rep No 106-71 at 122-23 (cited in note 3) (describing the process of consideration by the Foreign Relations Committee).

38 See Rule 9(b), Rules of Committee on Foreign Relations, S Doc No 106-6 at 99 (cited in note 37).

39 See Thomas W. Lippman, Seeking Liberation of Treaties in Limbo; Sen. Helms Wants Bipartisan Deal to Ratify or Scrap Shelved Accords that Date to 1949, Wash Post A27 (Feb 15, 1999) ("There they sit, years and even decades later, still nominally awaiting the Senate's advice and consent but mostly as dead as the Cold War.").

40 See Rule 9(d), Committee on Foreign Relations, S Doc No 106-6 at 99 (cited in note 37) ("Insofar as possible, the Committee should conduct a public hearing on each treaty."); Jerrold Zwirn, Congressional Publications and Proceedings: Research on Legislation, Budgets, and Treaties 231 (Libraries Unlimited 2d ed 1988) ("Though the Senate rules do not require the Foreign Relations Committee to schedule hearings or issue a report, such action is customary.").

41 See id at 231-33 (discussing the alternative recommendations available to the Foreign Relations Committee). Conditional approval manifests itself in amendments, reservations, understandings, declarations, and provisos. See S Rep No 106-71 at 124-26 (cited in note 3) (describing the tools of conditional approval).

42 It is important to note that the Senate ultimately votes on a resolution of ratificationthe resolution does not ratify the treaty. See S Rep No 106-71 at 142 (cited in note 3) ("The final vote on agreeing to the resolution of ratification requires a two-thirds majority of those present and voting for approval."); id at 147 ("[T] he President is then free to ratify the treaty if he so chooses."). The significance of the ratification power residing in the President and not the Senate is discussed below in Part I.A.3.

43 See id at 136 (describing the resolution of ratification).

44 For an example of treaty consideration by the entire Senate, see 141 Sen Exec J 457-60, 478-79 (1999) (presenting consideration of the CTBT).

45 See Rule XXX(1)(b), S Doc No 106-15 at 39 (cited in note 34 ).

46 See Rule XXX(1)(c), S Doc No 106-15 at 39 (cited in note 34).

47 Id. 
thirds of the senators present to succeed. ${ }^{43}$ Should two-thirds of the Senate consent, the treaty passes back to the President for final ratification. ${ }^{49}$ Should the vote fail, the Senate may adopt a resolution, by majority vote, ${ }^{50}$ returning the treaty to the President, or else the treaty returns to the Senate Executive Calendar. ${ }^{\text {s1 }}$ Any treaty remaining on the Executive Calendar at the end of a Congress is referred back to the Foreign Relations Committee, where it remains pending future action. ${ }^{52}$ In summary, the Senate may approve through consent or conditional consent. The Senate may also disapprove through rejection, inaction, or incomplete action.

\section{Subsequent action by the President.}

Upon receiving Senate consent, the President then ultimately decides whether to ratify the treaty, finalizing the process. ${ }^{54}$ Ratification consists of a two-step process where the President: (1) signs and seals an instrument of ratification (a national act); and then (2) exchanges the instrument of ratification with the other party to the treaty (an international act). ${ }^{s 5}$ Upon ratifying, the President makes clear the

48 See US Const Art II, \$ 2, cl 2 ("provided two thirds of the Senators present concur"); Rule XXX(1)(d), S Doc No 106-15 at 39 (cited in note 34) ("On the final question to advise and consent to the ratification in the form agreed to, the concurrence of two-thirds of the Senators present shall be necessary to determine it in the affirmative.").

49 See S Rep No 106-71 at 143 (cited in note 3) (describing the transition of an approved treaty from the Senate to the Executive).

so See Rule XXX(1)(d), S Doc No 106-15 at 39 (cited in note 34) ("[A]ll other motions and questions upon a treaty shall be decided by a majority vote.").

51 See S Rep No 106-71 at 143 (cited in note 3) (describing procedure for a treaty failing to receive two-thirds consent).

52 See Rule XXX(2), S Doc No 106-15 at 39-40 (cited in note 34) ("[A]11 proceedings on treaties shall terminate with the Congress, and they shall be resumed at the commencement of the next Congress as if no proceedings had previously been had thereon."). See also Return of Certain Old Treaties to the President, 80th Cong, 1st Sess, in 93 Cong Rec S 3583 (April 17, 1947) (statement of Senator Vandenburg) (" $[U]$ nder the law and practice, whenever the President ... sends treaties to the Senate they remain on the calendar of the Senate Committee on Foreign Relations from one Congress to another."); Marjorie M. Whiteman, 14 Digest of International Law $\S 8$ at 61 (GPO 1970) ("A treaty may remain pending in the Senate, carried on the Treaty Calendar from session to session.") (internal citations omitted).

53 See Zwirn, Congressional Publications at 235-36 (cited in note 40) (describing the Senate's options in considering a treaty).

54 See Henkin, Foreign Affairs at 184 (cited in note 20) ("Once the Senate has consented, the President is free to make (or not to make) the treaty and the Senate has no further authority in respect of it."); S Rep No 106-71 at 147 (cited in note 3) ("[T]he President is then free to ratify the treaty if he so chooses"). For a list of treaties approved by the Senate but never ratified by the President prior to 1929, see Dangerfield, In Defense of the Senate at 349-50 (cited in note 31).

55 In the case of a multilateral treaty, the President deposits the instrument of ratification at a specified location. See S Rep No 106-71 at 149 (cited in note 3) ("In the case of multilateral treaties, such agreements generally enter into force after the deposit of a specified number of instruments of ratification at a specified location.").

56 See id at 147-50 (describing the process of ratification); Aust, Modern Treaty Law at 8187 (cited in note 29) (same). 
United States's consent to be bound by the treaty. ${ }^{57}$ In contrast to the obligation attendant to a signature, the obligation created by ratification gives the treaty full effect.

If the treaty does not receive two-thirds consent, and the Senate fails to adopt a resolution of return, the treaty remains in the Senate. ${ }^{38}$ In order to retrieve the treaty, the President must initiate proceedings

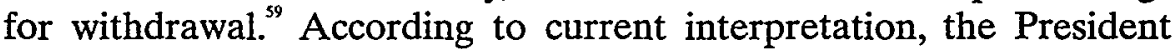
must obtain Senate consent before withdrawing a treaty. ${ }^{60}$ This position appears to rest on theories of property ${ }^{61}$ and simple custom, ${ }^{62}$ and sometimes on no citation or justification at all. ${ }^{63}$

\section{B. Article 18 of the Vienna Convention}

The Vienna Convention on the Law of Treaties ${ }^{64}$ attempted to codify international treaty practice. Article 18 reads:

A State is obliged to refrain from acts which would defeat the object and purpose of a treaty when:

(a) it has signed the treaty or has exchanged instruments constituting the treaty subject to ratification, acceptance or approval, until it shall have made its intention clear not to become a party to the treaty. ${ }^{6.5}$

57 However, it is possible that a treaty ratified by the U.S. will not enter into force if the other party fails to ratify. See Aust, Modern Treaty Law at 131 (cited in note 29) ("[W] hen a state expresses its consent to be bound it does not necessarily mean that the treaty will enter into force for it at that time: that will depend on whether the treaty is already in force ... or whether further consents are needed to bring it into force.").

58 See notes 50-52 and accompanying text.

59 See S Rep No 106-71 at 145 (cited in note 3) (describing the process for the return or withdrawal of a treaty).

60 See note 3.

61 See Glennon, Constitutional Diplomacy at 174-75 (cited in note 3) ("Nonetheless, practicality argues against such presidential authority, since at that point the Senate, not the President, has custody of the official treaty documents; they are not then within the President's control."). For further discussion of this view, see note 87. See also Shanker and Sanger, White House Wants to Bury Pact, NY Times at A1 (cited in note 2) ("Thus, once the test ban treaty was rejected by the Senate, it reverted to the legal property of the Senate Foreign Relations Committee."). This article cites to the advice of the State Department's legal office that the President lacks the power of unilateral withdrawal, but offers no direct justification. See id.

62 See Glennon, Constitutional Diplomacy at 175 (cited in note 3) ("[C]ustom apparently supports a requirement that the President seek Senate consent for the withdrawal of a disfavored treaty."). For further discussion of this view, see Part III. Professor Glennon appears hesitant to fully embrace the position that the President may not unilaterally withdraw a treaty, qualifying his assertions with phrases like "practicality argues" and "custom apparently supports." Id at 174-75.

63 See S Rep No 106-71 at 145 (cited in note 3) (offering no support for the naked proposition that the President lacks authority to withdraw a treaty from the Senate without consent).

64 Vienna Convention, 8 ILM at 679 (cited in note 11).

65 Vienna Convention, Art 18(a), 8 ILM at 686 (cited in note 11). 
The United States has signed, but not yet ratified, the Vienna Convention. ${ }^{6}$ As a result, the Vienna Convention is not legally binding on the U.S. as a treaty. ${ }^{67}$ However, there is strong support for the proposition that the U.S. must adhere to Article 18, and uphold the obligation to refrain from acting in a way that would defeat the object and purpose of a signed treaty. First, Article 18 probably codified customary international law, which is binding on all nations. ${ }^{68}$ Second, the U.S. has "long recognized such an obligation." ${ }^{69}$ Third, the Restatement (Third) of the Foreign Relations Law of the United States adopts the view of Article $18 .^{70}$ Finally, the U.S. must adhere to the obligation of Article 18 for the functional reason that all of the nations with which it makes treaties view the obligation attendant to signature as binding.

As the language suggests, Article 18 becomes effective when the President signs a treaty. The obligation imposed applies for the period between signature and ratification, which includes consideration by the Senate. ${ }^{\text {D }}$ During this period, the U.S. must "refrain from acts which

66 S Rep No 106-71 at 43 (cited in note 3).

67 See id ("[T]hus [the U.S.] is not legally bound by its provisions.").

6S See Glennon, Constitutional Diplomacy at 171 (cited in note 3) ("[T]he better view appears to be that Article 18 codified international law as it existed at the time the Vienna Convention was adopted."); Joni S. Charme, The Interim Obligation of Article 18 of the Vienna Convention on the Law of Treaties: Making Sense of an Enigma, 25 Geo Wash J Intl L \& Econ 71, 77 (1991) ("This article adopts the persuasive position that article 18 codified the existing interim obligation and continues to embody this norm."); Rogoff, 32 Maine L Rev at 284 (cited in note 28) ("Article 18 represents the codification of a rule of customary international law, as it was developed in the decisions of international tribunals and state practice, and was refined in the work of the International Law Commission and the Vienna Conference on the Law of Treaties."). See also Glennon, Constitutional Diplomacy at 171-72 n 51 (cited in note 3) (listing several additional authorities endorsing this view). But see id at 171 n 50 (listing authorities adopting the view that Article 18 instead represents progressive development of new international law).

69 Glennon, Constitutional Diplomacy at 172 \& n 54 (cited in note 3) (citing to a statement by former Secretary of State John Hay). For the Senate's current position see S Rep No 106-71 at 113 (cited in note 3) ("During this interim period the treaty is not yet in effect, but under international law nations have an obligation not to do anything that would defeat the purpose of the treaty."). Similarly, the Clinton Administration endorsed the view that Article 18 applied to the CTBT. See note 12 .

70 See Restatement (Third) of Foreign Relations Law at § 312(3) (cited in note 14) ("Prior to the entry into force of an international agreement, a state that has signed the agreement or expressed its consent to be bound is obliged to refrain from acts that would defeat the object and purpose of the agreement.").

71 See Aust, The Modern Treaty Law at 10 (cited in note 29) ("When questions of treaty law arise during negotiations, whether for a new treaty or about one concluded before the entry into force of the Convention, the rules set forth in the Convention are invariably relied upon even when the states are not parties to it."); S Rep No 106-71 at 43 (cited in note 3) ("[T] he convention retains its status as a primary source of international law concerning treaties, even for non-parties.").

72 See S Rep No 106-71 at 113 (cited in note 3) (describing the interim period of obligation as including "Senate consideration"). 
would defeat the object and purpose of [the] treaty.", This has been interpreted to mean the U.S. must "not do anything which would affect its ability fully to comply with the treaty once it has entered into force." ${ }^{\text {,74 }}$ Similarly, the Restatement frames the test in terms of irreversibility. ${ }^{75}$ For example, having signed the CTBT, by testing a nuclear weapon the U.S. would certainly be acting in a way that defeats the object and purpose of the treaty. ${ }^{76}$ The irreversible act of testing a weapon would explicitly violate the treaty, preventing the U.S. from carrying it out.

Furthermore, escaping the interim obligation imposed by Article 18 requires that the U.S. make "its intention clear not to become a party to the treaty." Because the act of signing invokes the Article 18 obligation, it follows that the President can negate it by "un-signing" the treaty. ${ }^{78}$ By withdrawing a signed treaty from the Senate and "unsigning" it, the President makes clear the intention not to become a party."

The discussion above reveals two potential problems. First, the Senate's denial of a request made by the President for the return of a treaty might violate the constitutional allocation of presidential powers. Second, the combination of the Senate's ability to deny such a request by the President and the obligation not to defeat the object and purpose of a signed treaty creates a binding commitment while circumventing the requirements of the Treaty Clause. These problems raise the question of whether the President may unilaterally withdraw

73 Vienna Convention, Art 18(a), 8 ILM at 686 (cited in note 11).

74 Aust, Modern Treaty Law at 94 (cited in note 29). Aust continues, "Thus, if the treaty obligations are premised on the status quo at the time of the signature, doing something before entry into force which alters the status quo in a way which would prevent the state from performing the treaty would be a breach of the article." Id. The CTBT certainly fits into this category as "premised on the status quo," and testing a nuclear weapon would alter the status quo such that the U.S. could not perform the treaty because it bans testing weapons.

75 See Glennon, Constitutional Diplomacy at $170 \mathrm{n} 44$ (cited in note 3) ("The Restatement applies a standard of irreversibility.").

76 See Restatement (Third) of Foreign Relations at \$ 312, comment i ("Testing a weapon in contravention of a clause prohibiting such a test might violate the purpose of the agreement, since the consequences of the test might be irreversible.").

77 Vienna Convention, Art 18(a), 8 ILM at 686 (cited in note 64).

78 See Aust, Modern Treaty Law at 95-96 (cited in note 29) (discussing the right to withdraw consent to a treaty).

79 See Glennon, Constitutional Diplomacy at 173-74 (cited in note 3) ("[I]f it wishes to signal a definite end to obligations under article 18, the Senate is best advised simply to return the treaty to the President."); id at 174 ("Should the President wish to signal a definite end to obligations called for by article 18 under a signed treaty, he would be best advised to request its return from the Senate and to indicate in a formal message to the Senate that he does not intend to cause the United States to become a party."). Professor Glennon, however, finds that the President may not withdraw a treaty from the Senate without consent, see id at 174-75, but he seems to suggest that the President might negate Article 18 obligations simply by declaring his intent not to ratify the treaty. See id at 174 . For further discussion of this view, see Part IV below. 
a signed treaty from the Senate for the purpose of negating the consequences of signature.

\section{CONSTITUTIONAL LAW OF TREATY WITHDRAWAL: TEXTUAL, STRUCTURAL, AND FUNCTIONAL ARGUMENTS}

The Constitution governs the treaty-making process, including the respective roles of both the President and the Senate. Interpreting the Constitution with regard to presidential power to "un-sign" treaties requires the examination of several theories. It is necessary to look to the text and structure of the Constitution, and also to functional considerations.

\section{A. The Text of the Constitution}

The language of the Constitution does not always provide explicit answers. Examining the text requires looking at both direct and indirect arguments.

1. Direct arguments from the text.

The Constitution addresses treaties in the Treaty Clause, which provides: "He [the President] shall have Power, by and with the Advice and Consent of the Senate, to make Treaties, provided two thirds of the Senators present concur." ${ }^{80}$

On its face, the language does not reveal anything about the withdrawal of treaties. The clause appears to simply grant to the President the power to make treaties. As with most powers granted by the Constitution to one branch of government, a check accompanies the President's treaty-making power: two-thirds of "the Senators present ${ }^{\text {, }}$ must vote to consent to the treaty. ${ }^{82}$ However, it is important

80 US Const Art II, \$2, cl 2.

81 See Henkin, Foreign Affairs at 37 (cited in note 20) (noting that "[t]he Constitution requires consent of two-thirds of the Senators present, not two-thirds of the total membership of the Senate").

82 See id at 178 ("The requirement of Senate consent is an important 'check' on Presidential power to make foreign policy by treaty."). One might argue that the President and the Senate share the power to make treaties, or that they make treaties together. See Dangerfield, In Defense of the Senate at 32-33 (cited in note 31) (describing Senator Henry Cabot Lodge's theory that "except for the Senate's want of authority to send or receive ambassadors and ministers and the resultant inability to initiate negotiations, the treaty power is vested both in the President and in the Senate on a basis of perfect equality"); William Whitwell Dewhurst, Does the Constitution Make the President Sole Negotiator of Treaties?, 30 Yale L J 478, 479 (1921) (claiming the Constitution empowers the Senate to act jointly with the President in negotiating treaties). However, this idea mischaracterizes the process, understating and overstating presidential and senatorial roles respectively. See Henkin, Foreign Affairs at 37 (cited in note 20) ("It is the President who makes treaties, if the Senate consents; the Senate cannot make a treaty. The President need not make a treaty, even if the Senate, or Congress, demands it."). See also Corwin, The President at 241 (cited in note 22) ("In short, the Senate's role in treaty making is nowadays sim- 
initially to observe that the Treaty Clause makes an affirmative grant of power to the President.

Because the Treaty Clause grants to the President the power "to make Treaties," the examination must next determine the content or substance of that power. The power to "make" a treaty refers to the ratification of the document by the President. ${ }^{83}$ Ratification constitutes the final act in the treaty-making process. ${ }^{\text {st }}$ Thus, the President possesses the power to both initiate and finalize the treaty, while the Senate plays only an intermediate, but still significant, role. The idea that the President has the first and last say on the matter displays his predominance in treaty-making.

Furthermore, the President's ultimate power to ratify, or finalize, the treaty itself holds great importance for the question of treaty withdrawal. First, this power means that the President may refuse to submit a negotiated and signed treaty to the Senate. ${ }^{85}$ History reveals numerous occasions where the Chief Executive has chosen to withhold signed treaties from the Senate. ${ }^{86}$ Second, after submitting a treaty and receiving the Senate's consent, the President then has the choice of whether to ratify the treaty. Because it is clearly within his power to refuse to ratify the treaty, it follows that the President has the power to withdraw unilaterally a disfavored treaty from the Senate. ${ }^{87}$ This view of the President's unilateral power relies on a greater-

ply ... that of veto."); Dangerfield, In Defense of the Senate at 213 (cited in note 31) ("As the Senate has repeatedly exercised a veto over the President's power to appoint, so it has exercised a veto over his treaty-making power.").

83 See Henkin, Foreign Affairs at 177 (cited in note 20) ("The Senate gives consent to making the treaty, the President makes it."). See also Corwin, The President at 241 (cited in note 22) ("the act of ratification being the President's").

84 See Part I.A.3.

85 See Crandall, Treaties at 83 (cited in note 19) ("As all treaties must receive this final ratification, the President may at will, so far as depends on his constitutional power, withhold from the Senate a treaty already negotiated.").

86 See, for example, id (listing withheld treaties). For a list of treaties never submitted by the President to the Senate from the Founding until 1920, see Dangerfield, In Defense of the Senate at 349 (cited in note 31 ).

87 See Glennon, Constitutional Diplomacy at 174 (cited in note 3):

Because the President (should the Senate give its consent) retains the discretion to decline to proceed to ratification, it might seem sensible that the President can withdraw a treaty from the Senate without its consent; after all, Senate consideration of the treaty would be pointless if it was clear from the outset that ratification by the President would not follow.

Professor Glennon disregards this argument citing the customary requirement of a presidential request for return. Id at 175 . See also note 62 . Glennon asserts a property theory in support of his position, stating, "Nonetheless, practicality argues against such presidential authority, since at that point the Senate, not the President, has custody of the official treaty documents; they are not then within the President's control." Id at 174-75. However, custody of the documents does not provide a compelling justification. Just as plausibly, submitting a treaty might create a bailment pursuant to a contract, in which case the President retains ownership. 
includes-the-lesser argument: ${ }^{8}$ the President's ultimate constitutional authority regarding treaty ratification strongly suggests he has the power to withdraw treaties from the Senate unilaterally in order to "un-sign" them.

\section{Indirect arguments from the text.}

While the text of the Treaty Clause appears to directly support unilateral presidential power to withdraw treaties, the Constitution provides other important textual clues. First, the Vesting Clause of Article II provides grounds for broad presidential power in foreign affairs." Alexander Hamilton advanced the theory that "the executive Power" vested in the President includes all foreign affairs powers not explicitly granted to other branches. ${ }^{90}$ Hamilton interpreted the linguistic difference between Article I, vesting "[a]ll legislative Powers herein granted" in Congress, ${ }^{\text {91 }}$ and Article $\Pi$, vesting "[t] Power" in the President, ${ }^{\text {s2 }}$ as limiting Congress to its enumerated powers while granting the President the whole executive power not limited by enumeration. At the time of the framing of the Constitution, foreign relations powers were widely considered "executive" in nature. Therefore, under Hamilton's theory, the President retains authority in foreign relations except where the Constitution explicitly states otherwise. Similarly, President Theodore Roosevelt adopted

88 Crandall appears to accept this logic in his discussion of the President's constitutional role in treaty ratification. See Crandall, Treaties at 82-85 (cited in note 19) (emphasis added):

Although treaty negotiations are conducted through the Secretary of State, they originate legally with the President. Treaties are signed by the Secretary of State, as well as by other agents, and the ratifications are exchanged on the authority of powers conferred by the President. The power of ratification is not delegated.

As all treaties must receive this final ratification, the President may at will, so far as depends on his constitutional power, withhold from the Senate a treaty already negotiated.... Or the treaty may be submitted, accompanied with recommendations for amendments....

So also treaties may be withdrawn from the consideration of the Senate either to effect changes by negotiation or to terminate proceedings on them.

89 See US Const Art II, $\S 1, \mathrm{cl} 1$ ("The executive Power shall be vested in a President of the United States of America.").

90 See Harold C. Syrett and Jacob E. Cooke, eds, 15 The Papers of Alexander Hamilton 39 (Columbia 1969) ("The general doctrine then of our constitution is, that the EXECUTIVE POWER of the Nation is vested in the President; subject only to the exceptions and $q u[a]$ lifications which are expressed in the instrument.").

91 US Const Art I, $\$ 1$.

92 US Const Art II, $\$ 1, \mathrm{cl} 1$.

93 See Syrett and Cooke, eds, 15 Papers of Alexander Hamilton at 38-39 (cited in note 90) (comparing Article I's Vesting Clause with that of Article II).

94 See Corwin, The President at 462-64 (cited in note 22) (quoting Blackstone, Locke, and Montesquieu on the executive nature of foreign relations powers).

95 While the Hamiltonian view has sustained criticism, see, for example, Youngstown Sheet \& Tube Co v Sawyer, 343 US 579, 641 (1952) (Jackson concurring) ("I cannot accept the view 
the view that the President acts as a "steward of the people,", not limited to those powers enumerated in the Constitution, but only by express prohibitions." The Constitution does not expressly limit the President's authority to withdraw treaties from the Senate unilaterally or grant that power to another branch. Therefore, because the power of unilateral withdrawal involves foreign affairs, it is encompassed by the President's executive power.

Second, much of the President's foreign affairs power arises implicitly from the enumerated powers. For example, the power to appoint and receive ambassadors has been found to include the power to recognize foreign governments and establish relations with them. ${ }^{\text {s. }}$ The authority to withdraw a treaty unilaterally might easily be argued as residing implicitly in the President's treaty power.

Furthermore, these foreign relations powers involve the channels of communication between nations, which the President controls. As John Marshall stated, he is the "sole organ of the nation in its external relations, and its sole representative with foreign nations." United States's spokesperson and representative in foreign relations, the President directs how, when, where, and by whom interactions

that this clause is a grant in bulk of all conceivable executive power but regard it as an allocation to the presidential office of the generic powers thereafter stated."); Lawrence Lessig and Cass Sunstein, The President and the Administration, 94 Colum L Rev 1, 47-48 n 195 (1994) ("[T]he [Article II] Vesting Clause does nothing more than show who ... . is to exercise the executive power, and not what that power is."), the theory has experienced a resurgence of late. Professors Prakash and Ramsey recently advanced a theory of textual interpretation, similar to Hamilton's argument, that grants the President broad foreign affairs powers as part of the executive power. See Saikrishna B. Prakash and Michael D. Ramsey, The Executive Power over Foreign Affairs, 111 Yale L J 231, 252-61 (2001) (arguing that the President has an all-encompassing residual foreign affairs power as part of the executive power, and that Congress's foreign affairs powers do not exceed enumeration).

96 Theodore Roosevelt: An Autobiography 357 (Charles Scribner's Sons 1929).

97 See id ("I declined to adopt the view that what was imperatively necessary for the $\mathrm{Na}$ tion could not be done by the President unless he could find some specific authorization to do it. My belief was that it was not only his right but his duty to do anything that the needs of the $\mathrm{Na}$ tion demanded unless such action was forbidden by the Constitution or by the laws.").

98 See Goldwater v Carter, 444 US 996, 1007 (1979) (Brennan dissenting) ("Our cases firmly establish that the Constitution commits to the President alone the power to recognize, and withdraw recognition from, foreign regimes."); Banco Nacional de Cuba v Sabbatino, 376 US 398, 410 (1964) ("Political recognition is exclusively a function of the Executive.").

9910 Annals of Congress 613 (Gales and Seaton 1851) (statement of John Marshall). John Marshall described the President in these terms during his argument in the House of Representatives in support of President John Adams's decision to extradite Jonathan Robbins, a supposed American citizen accused of murder on a British vessel, to Great Britain in accordance with a treaty. See Henkin, Foreign Affairs at 339 n 19 (cited in note 20). See also United States $v$ CurtissWright Export Corp, 299 US 304, 319 (1936) (quoting Marshall); Restatement (Third) of Foreign Relations Law at $\S 1$, Reporters' Note 2 (cited in note 14) (same). Alexander Hamilton used similar language in his defense of President Washington's Neutrality Proclamation. See Syrett, and Cooke, eds, 15 Papers of Alexander Hamilton at 38 (cited in note 90) ("[Declaring neutrality] appears to be connected with [the executive] department in various capacities, as the organ of intercourse between the Nation and foreign Nations."). 
with other nations transpire. ${ }^{100}$ This authority inevitably incorporates a degree of content-control, such that the President acts as a policymaker. ${ }^{109}$ As the "sole organ" the President should control the nation's position on a treaty, including situations involving unilateral withdrawal from Senate consideration.

The text appears to provide direct support for the President's power to withdraw treaties without Senate consent. But should the plain text of the Treaty Clause need reinforcement, the Hamiltonian view, implicit powers, and the "sole organ" theory provide strong supplementary support for the President.

\section{B. The Structure of the Constitution}

The structure of the Constitution is also relevant in determining relative roles in the treaty-making process. First, the Constitution separates the federal government into three distinct branches: legislative, executive, and judicial. Each branch is discussed, and its specific powers enumerated, in a different subdivision. Article I deals with the legislature (the Congress), Article III with the judiciary (the federal courts), and Article II addresses the executive (the President). Therefore, the fact that the Framers inserted the Treaty Clause in Article II implies treaty-making is primarily a function of the President. ${ }^{102}$ The power to withdraw a treaty, therefore, should also fall under the President's Article II powers.

Next, the Appointments Clause ${ }^{103}$ presents the best constitutional analogy for the question at hand. Whether the President has the constitutional authority to withdraw a treaty unilaterally might reasonably correspond with whether he can withdraw nominations without consent. The Framers' decision to include the Treaty Clause and the Appointments Clause together in the same paragraph, sharing very similar language, supports their common interpretation. ${ }^{\text {104 }}$ The Appointments Clause provides:

100 See Henkin, Foreign Affairs at 42 (cited in note 20) ("As 'sole organ', the 'President determines also how, when, where, and by whom the United States should make or receive communications, and there is nothing to suggest that he is limited as to time, place, form, or forum.").

101 For a discussion of the President's ability to make policy as the "sole organ," see id at 41-45.

102 Note that Article I does mention treaties for the purpose of barring states from making them, US Const Art I, $\S 10$, cl 1 ("No State shall enter into any Treaty"), but this reference does not bear on the issue here because it simply places a prohibition on the states, and makes no affirmative grant of power. Article I, $\S 10$, provides a list of things the states cannot do. Placement of the treaty prohibition in Article I, rather than Article II probably results from the need to locate these proscriptions together.

103 US Const Art II, \$ 2, cl 2.

104 Professor Tribe analogizes between the two clauses in discussing presidential authority to decline to ratify a treaty after submitting it to the Senate. Laurence H. Tribe, Taking Text and Structure Seriously: Reflections on Free-Form Method in Constitutional Interpretation, 108 Harv L 
[The president] shall nominate, and by and with the Advice and Consent of the Senate, shall appoint Ambassadors, other public Ministers and Consuls, Judges of the supreme Court, and all other Officers of the United States, whose Appointments are not herein otherwise provided for, and which shall be established by Law. ${ }^{105}$

As with treaties, the President initiates nominations, and the Senate provides a check through "advice and consent." The allocation of powers between the President and the Senate in appointments very nearly mirrors that of the treaty process. ${ }^{106}$ And, in short, the President has authority to withdraw nominations from the Senate at will. ${ }^{107}$ Historical practice shows the President acts with this authority on a regular basis. ${ }^{108}$ Nomination withdrawals proceed in a similar fashion as treaty withdrawals-by a message from the President. ${ }^{109}$ Because the

Rev 1221, 1253 n 108 (1995) ("[A] President may of course prevent a treaty from going into effect even after he has submitted it for Senate ratification, just as the President may withdraw the nomination of a principle officer."). Interestingly, Professor Henkin asserts that "the Senate can probably withdraw, modify, or impose conditions on consent it had given, before the President concludes the treaty." Henkin, Foreign Affairs at 179 (cited in note 20). He analogizes to the appointments process, basing the proposition on the idea that the Senate might be able to withdraw its consent to a nomination prior to the appointee taking office. See id at 399-400 n 103,448 $n 20$. These remain open questions, but if the Senate can withdraw its consent to a treaty prior to ratification, this suggests the President can unilaterally withdraw a treaty before the Senate approves it.

105 US Const Art II, § 2, cl 2.

106 One might object that the President withdraws nominations prior to a Senate vote, whereas he sometimes may withdraw treaties that have already received a negative vote. However, the Senate can reconsider its vote on a nomination, which is similar to reconsidering a previously rejected treaty. See Joseph P. Harris, The Advice and Consent of the Senate: A Study of the Confirmation of Appointments by the United States Senate 257 (Greenwood 1968) (describing the Senate's options in reconsidering a vote on a nomination). If the President can withdraw a nomination prior to a vote, there is no reason to think he can not withdraw it during reconsideration of a vote.

107 See Tribe, 108 Harv L Rev at 1253 n 108 (cited in note 104) ("[T]he President may withdraw the nomination of a principal officer."); Louis Fisher, Constitutional Conflicts between Congress and the President 22 (Kansas 4th ed 1997) ("Nomination (at least in theory) is the President's prerogåtive.... After submitting a name the President may, and often does, withdraw it.").

108 See G. Calvin Mackenzie, The Politics of Presidential Appointments 176 (Free Press 1981) ("A number of nominations are withdrawn in each session of Congress, but withdrawal comes for a wide range of reasons."); Fisher, Constitutional Conflicts at 37 (cited in note 107) ("Although the record demonstrates that the Senate only infrequently rejects a nomination to an executive position, statistics do not reveal ... the names withdrawn by the President after confirmation becomes hopeless."); The Senate Role in Foreign Affairs Appointments, 92d Cong, 1st Sess 13-16 (1971) (providing historical examples of presidential withdrawal of foreign affairs nominations).

109 Recent volumes of the Senate Executive Journal provide a list of nominations withdrawn by the President during a particular session of Congress. See, for example, 142 Sen Exec J 574 (2000) (providing a list of nominations withdrawn in the second session of the 106th Congress); 141 Sen Exec J 576 (1999) (providing a list for the first session of the 106th Congress); 140 Sen Exec J 615 (1998) (providing a list for the second session of the 105th Congress). The most recent presidential withdrawals can be found in Senate Foreign Relations Committee, Legislative 
withdrawal under the appointment power seems closely analogous to the withdrawal under the treaty power, the fact that the President can withdraw nominations at will supports the conclusion that he can also unilaterally withdraw treaties.

Finally, the President appears to have the constitutional authority to terminate ratified treaties unilaterally. Because such an act nullifies the Senate's grant of consent, it follows that he can unilaterally end Senate consideration of a signed treaty that has not yet received consent."

On December 13, 2001, President Bush announced that the United States would withdraw from the Anti-Ballistic Missile Treaty ("ABM Treaty")," signed with the Soviet Union in 1972." The President terminated the treaty in accordance with Article XV of the treaty, which provided that either party could withdraw, upon six months notice, if circumstances relating to ABM threatened the interests involved. ${ }^{113}$ Notably, Bush acted unilaterally, without obtaining the consent of the Senate or Congress, despite the view that one of those bodies has a role in treaty termination. ${ }^{114}$ This instance brings to mind President Carter's decision to terminate a mutual-defense treaty with Taiwan unilaterally in accordance with the recognition of mainland China, which culminated in a suit brought by members of Congress that went up to the Supreme Court. ${ }^{115}$ The Court of Appeals for the District of Columbia held the President acted within his constitutional authority. ${ }^{16}$ In a plurality opinion, the Supreme Court declined to de-

Activities: Nominations Withdrawn, available online at <http://www.senate.gov/legislative/ legis_act_nominations_withdraw.html> (visited Feb 2,2002).

110 Note that, to an extent, this claim parallels the greater power includes the lesser power argument with regards to the President declining to ratify a treaty. See text accompanying notes 85-88.

111 Treaty on the Limitation of Anti-Ballistic Missile Systems, US-USSR, 23 UST 3435, TIAS No 7503 (1972).

112 See From Bush, 'Formal Notice' of End of Pact, NY Times A14 (Dec 14, 2001) (excerpting the text of President Bush's remarks in announcing the termination of ABM). See also David E. Sanger and Elisabeth Bumiller, U.S. to Pull out of ABM Treaty, Clearing Path for Antimissile Tests, NY Times A1 (Dec 12,2001) (describing President Bush's decision and its consequences).

113 See id.

114 See Bruce Ackerman, Treaties Don't Belong to Presidents Alone, NY Times A23 (August 29,2001 ) (urging the Senate to contest unilateral presidential action and "defend its role in foreign policy"); Dana Milbank, Growing Conflict over Presidential Powers, Wash Post A8 (Dec 15, 2001) (presenting complaints from senators that they were not consulted). But see Jack Goldsmith and John Yoo, Missile Defense Defense, Am Lawyer 69, 70 (Apr 2001) ("President Bush has the legal power to decide that the United States will withdraw from the ABM treaty.").

115 See Goldwater $v$ Carter, 444 US 996 (1979) (declining to decide whether President Carter had the authority to terminate the Taiwan treaty unilaterally). For a thorough account of the affairs surrounding President Carter's termination of the treaty with Taiwan, see Victoria Marie Kraft, The US Constitution and Foreign Policy: Terminating the Taiwan Treaty 143-67 (Greenwood 1991).

116 Goldwater v Carter, 617 F2d 697, 709 (DC Cir 1979) ("We find the president did not ex- 
cide, based on ripeness and justiciability grounds, whether the President may unilaterally terminate a treaty. ${ }^{17}$ Only Justice Brennan reached the merits of the case, upholding the President's actions as "a necessary incident to Executive recognition of the Peking Government." ${ }^{118}$ If the President can terminate a treaty without consulting the Senate, then it seems reasonable to think that he can also unilaterally withdraw one, in effect terminating it before Senate consideration.

The issue of treaty termination has received much attention, especially since President Carter's actions. ${ }^{119}$ Commentators have not agreed on the allocation of power in treaty termination, ${ }^{120}$ and the text of the Constitution provides little help. ${ }^{121}$ Furthermore, interpretations of the Framers' intent ${ }^{122}$ and historical practice ${ }^{123}$ have led to ambiguous

ceed his authority when he took action to withdraw from the ROC [Republic of China] treaty, by giving notice under Article $\mathrm{X}$ of the Treaty, without the consent of the Senate or other legislative concurrences."), vacd without reaching the merits, 444 US 996 (1979).

117 Goldwater, 444 US at 996. Then-Justice Rehnquist, joined by three others, found the issue a political question, id at 1005 , while Justice Powell found the case not ripe for review, id at 998.

118 Id at 1007.

119 For a partial list of articles published on the subject, see Glennon, Constitutional Diplomacy at $146 \mathrm{n} 130$ (cited in note 3 ).

120 Professor Henkin provides a good discussion of the debate. See Henkin, Foreign Affairs at 211-14 (cited in note 20).

121 See Prakash and Ramsey, 111 Yale L J at 249 (cited in note 95) ("Nothing in the Constitution's text seems directly addressed to this question, and the leading proponents of each side quickly dismiss the text and reach for other authorities."). However, Professors Prakash and Ramsey assert that, while the Constitution does not explicitly grant the power to terminate a treaty, Article II's vesting of the executive power in the President includes the residual authority over foreign affairs. Id at 265 . They conclude that "[t]erminating a treaty in accordance with its express terms or with international law is a power not mentioned directly in the Constitution, but was obviously part of the traditional executive's foreign affairs power." Id.

122 Glennon, Constitutional Diplomacy at 151 (cited in note 3) ("The intent of the Framers is thoroughly ambiguous."). Compare Henkin, Foreign Affairs at 212 (cited in note 20) ("But perhaps the Framers were concerned only to check the President in 'entangling' the United States; 'disentangling' is less risky and may have to be done quickly, and is often done piecemeal, or ad hoc, by various means and acts."), and Prakash and Ramsey, 111 Yale $\mathrm{L} J$ at 327 (cited in note 95) ("Given that in the eighteenth century the executive power was widely thought to include the treaty power, it is not surprising that Washington, Hamilton, and Jefferson believed that the President could decide whether to terminate or suspend a treaty."), with Arthur Bestor, Respective Roles of Senate and President in the Making and Abrogation of Treaties-The Original Intent of the Framers of the Constitution Historically Examined, 55 Wash L Rev 1, 135 (1979) (finding the "true intent of the framers" to be that "treatymaking was to be a cooperative venture from the beginning to the end of the entire process"), and David Gray Adler, The Constitution and the Termination of Treaties 112 (Garland 1986) ("It seems then wholly unrealistic to believe that the Framers would have unbalanced this carefully drafted system by not providing that the treaty-making power included the power to terminate treaties as well.").

123 See S Rep No 106-71 at 201-08 (cited in note 3) (describing various means by which treaties have been terminated by the U.S.); Whiteman, 14 Digest of Intl Law $\$ 38$ at 460-61 (cited in note 52) (same). Compare "President's Power to Give Notice of Termination of US-ROC Mutual Defense Treaty," Memorandum from Herbert J. Hansell, State Department Legal Advisor, to the Secretary of State (Dec 15, 1978), reprinted in Termination of Treaties: The Constitutional Allocation of Power 95th Cong, 2d Sess, 395, 397-98 (GPO 1978) (finding historical precedent for 
conclusions. However, despite disagreement among scholars, there is strong support for presidential authority in treaty termination.

First, the Restatement adopts this position, stating:

Under the law of the United States, the President has the power:

(a) to suspend or terminate an agreement in accordance with its terms;

(b) to make the determination that would justify the United States in terminating or suspending an agreement because of its violation by another party or because of supervening events, and to proceed to terminate or suspend the agreement on behalf of the United States; or

(c) to elect in a particular case not to suspend or terminate an agreement. $^{124}$

Second, President Bush's recent termination of ABM, building on President Carter's termination of the Taiwan treaty, coupled with the lack of a strong Senate response disputing the Presidents' actions, suggest that presidents believe they have unilateral power, and the Senate seems to accept this. ${ }^{125}$ Third, in the most recent court decision on the issue, the D.C. Circuit upheld the President's unilateral termination of a treaty. ${ }^{126}$ Finally, the only modern Supreme Court opinion on the merits of this question, Justice Brennan's, supports unilateral presidential authority. ${ }^{127}$ These factors point to the conclusion drawn by Professor Henkin, that: "At the end of the twentieth century, it is apparently accepted that the President has authority under the Constitution to denounce or otherwise terminate a treaty, whether such action on behalf of the United States is permissible under international law or would put the United States in violation." favor of the President, and, probably goes further to show undisputed presidential authority. This development supports the conclusion that the President can withdraw a treaty from the Senate without obtaining consent. If the President can terminate a ratified treaty at will, he

unilateral treaty termination by the President), with Jonathan York Thomas, The Abuse of History: A Refutation of the State Department Analysis of Alleged Instances of Independent Presidential Treaty Termination, 6 Yale Stud World Pub Order 27, 30 (1979) ("[N]one of these instances serves to substantiate the State Department claim that the President may withdraw from or terminate treaties on his own initiative.").

124 Restatement (Third) of Foreign Relations Law at $\S 339$ (cited in note 14).

125 "The sponsors of Senate Resolution 15 contended that Senate consent is required prior to the termination of any mutual-security treaty." Glennon, Constitutional Diplomacy at $146-47$ \& $n 133$ (cited in note 3). But "the Senate never adopted this resolution." Id at $147 \mathrm{n} 133$.

126 Goldwater v Carter, 617 F2d at 709.

127 See Goldwater, 444 US at 1006-07 (Brennan dissenting) (arguing to uphold President Carter's unilateral termination of the Taiwan treaty).

128 Henkin, Foreign Affairs at 214 (cited in note 20). 
surely can effectively terminate an unratified treaty through unilateral withdrawal.

\section{Functional Arguments}

Beyond the text and structure of the Constitution, the President enjoys certain practical advantages over other branches in the field of foreign affairs. ${ }^{29}$ These advantages include: unity of office, as opposed to the potential for conflict; secrecy; dispatch, unhindered by deliberative tendency; expertise and access to information; and availability. ${ }^{130}$ Functionally, these official qualities put the President in the best position to conduct foreign affairs. Justice Sutherland famously made this determination in United States $v$ Curtiss-Wright Export Corp, ${ }^{131}$ writing:

It is important to bear in mind that we are here dealing ... [with] the very delicate, plenary and exclusive power of the President as the sole organ of the federal government in the field of international relations....

$[\mathrm{H}] \mathrm{e}$, not Congress, has the better opportunity of knowing the conditions which prevail in foreign countries, and especially is this true in time of war. He has his confidential sources of information. He has his agents in the form of diplomatic, consular and other officials. Secrecy in respect of information gathered by them may be highly necessary, and the premature disclosure of it productive of harmful results.

The president's functional advantages have taken on even greater significance in the modern era. ${ }^{133}$ In the context of treaty withdrawal, unity of office, dispatch, and expertise seem most relevant. Removing a signed treaty from consideration involves making known the nation's position concerning an international agreement. Because the

129 See Corwin, The President at 201 (cited in note 22) ("[T]he President has, it is true, certain great advantages.").

130 See Federalist 64 (Jay), in Clinton Rossiter, ed, The Federalist Papers 390, 391 (Mentor 1961). The fact that the Framers recognized the practical benefits of the President's office indicates they measured these functional advantages in allocating constitutional powers. Therefore, in examining the power of treaty withdrawal under the Constitution, these become important considerations.

131299 US 304 (1936).

132 Id at 319-20.

133 See Henkin, Foreign Affairs at 32 (cited in note 20) ("In the second half of the twentieth century, the President's control of information and expertise has loomed overwhelming, as military technology and foreign intelligence have become more complex and the need for secrecy appeared more compelling."). But see id at 33 ("Congress acquired a huge and knowledgeable staff which could compete with the Executive branch in expertise and often even in information."). Although Congress has developed its own expertise, because the President controls the State Department, he probably maintains a significant advantage regarding treaties. 
President enjoys unity of office, he is better equipped than Congress to make a final, binding decision, free from objection. Similarly, the President has the ability to make such a decision swiftly when necessary, without having to deliberate. ${ }^{134}$ Finally, access to ambassadors and State Department officials, whose expertise on international agreements is unrivaled, constitutes an important strength of the President. These functional considerations point to the President having authority to withdraw treaties from the Senate without consent.

\section{CONSTITUTIONAL LAW OF TREATY WITHDRAWAL: HISTORICAL PRACTICE}

As the discussion above shows, arguments from the text and structure of the Constitution, as well as functional considerations, support presidential authority to withdraw treaties unilaterally. However, beyond these arguments, historical practice becomes an important part of the inquiry. ${ }^{135}$ Textual, structural, and functional arguments would lose their force if history showed the President and Senate agreed that unilateral withdrawal power did not exist. ${ }^{136}$ But if historical practice reveals a presidential power to withdraw treaties without the Senate's consent, then the constitutional arguments become significantly reinforced. Justice Frankfurter writes, "[d]eeply embedded traditional ways of conducting government cannot supplant the Constitution or legislation, but they give meaning to the words of a

134 One might object that deliberation serves an important function when difficult, potentially controversial, choices arise. However, public opinion and the elective process provide a political check that strongly encourages the President to deliberate and make thoughtful decisions when necessary.

135 See Glennon, Constitutional Diplomacy at 54-68 (cited in note 3) (describing the importance of custom in interpreting the Constitution); Gerhard Casper, Constitutional Constraints on the Conduct of Foreign and Defense Policy: A Nonjudicial Model, 43 U Chi L Rev 463, 465 (1976) ("An empirical concept of constitutional law, rooted in legal realism, rather than the prescriptive one, has been generally accepted when it comes to the Constitution and foreign affairs."). Indeed historical practice has played a major role in defining numerous foreign affairs powers. For example, Professors McDougal and Lans endorse the constitutionality of executive agreements based on practice: "For even if the widespread use of executive agreements in dealing with all kinds of problems was not within the conscious contemplation of the statesman who foregathered at Philadelphia ..., the continuance of the practice by successive administrations throughout our history makes its contemporary constitutionality unquestionable." Myres S. McDougal and Asher Lans, Treaties and Congressional-Executive or Presidential Agreements: Interchangeable Instruments of National Policy: I, 54 Yale L J 181, 291 (1945), quoted in Casper, Constitutional Constraints, $43 \mathrm{U}$ Chi L Rev at 479 (cited in note 135). Furthermore, the President's dominant role in negotiating treaties results largely from practice. See notes 21-22 and accompanying text; Corwin, The President at 241-42 (cited in note 22) ("So far as practice and weight of opinion can settle the meaning of the Constitution, it is today established that the President alone has the power to negotiate treaties with foreign governments.").

136 Professor Glennon apparently finds this to be true. See Glennon, Constitutional Diplomacy at 175 (cited in note 3) ("[C]ustom apparently supports a requirement that the President seek Senate consent for the withdrawal of a disfavored treaty."). 
text or supply them.."137 A long, helpful history exists of presidents withdrawing treaties from the Senate. ${ }^{134}$

This history begins with President Franklin Pierce's message of August 8th, 1856, which reads:

To the Senate of the United States:

With a message of the $23 \mathrm{~d}$ of June last I transmitted, for the consideration of the Senate, a convention for the mutual delivery of criminals, fugitives from justice in certain cases, and for other purpose, concluded at The Hague on the 29th of May last, between the United States and His Majesty the King of the Netherlands. Deeming it advisable to withdraw that instrument from the consideration of the Senate, I request that it may be returned to me. ${ }^{139}$

On the very same day, the Senate received the message and responded with an order reading:

Ordered, That the convention [of extradition with the Netherlands] be returned by the Secretary to the President of the United States, agreeably to the request contained in his message dated 9th August, instant. ${ }^{100}$

This exchange provides an initial model to which most later interactions conform: The president sends a written message to the Senate expressing his desire to withdraw a treaty and the Senate responds by issuing an order or resolution returning the treaty. ${ }^{14 t}$ Such practice might appear to suggest that the President must obtain the consent of the Senate before withdrawing a treaty. ${ }^{142}$ It follows from this view that the President lacks the power of unilateral withdrawal. But the his-

137 Youngstown Sheet \& Tube Co v Sawyer, 343 US 579, 610 (1952) (Frankfurter concurring).

138 For relevant data, see generally US Deptartment of State, List of Treaties Submitted to the Senate 1789-1934 (GPO 1935) (providing a detailed list of all treaties submitted to the Senate and their disposition, including withdrawal by the President); Christian L. Wiktor, ed, Unperfected Treaties of the United States of America 1776-1976 (Oceana 1976) (listing treaties that failed to enter into force for any number of reasons, including withdrawal by the President).

13910 Sen Exec J 140-41 (1856).

14010 Sen Exec J 142 (1856).

141 Whether the Senate responds with an order or with a resolution does not appear to be of any significance. Most likely the variance simply represents sloppy procedure.

142 See Glennon, Constitutional Diplomacy at 175 (cited in note 3) ("[C]ustom apparently supports a requirement that the President seek Senate consent for the withdrawal of a disfavored treaty."); id at 174 n 60 ("No instance has been identified ... in which the Executive "withdrew' a treaty from the Senate without its consent."). Indeed, this is the position of the Senate itself: "The President does not have the formal authority to withdraw a treaty from Senate consideration without the Senate's concurrence." S Rep No 106-71 at 145 (cited in note 3). Of course the Senate's current position on the question does not resolve it, and, in fact, appears contrary to historical practice as will be shown below. See Part III.A. 
torical record suggests otherwise. This Comment will examine the actions of the President, the Senate, and finally a very revealing pair of interchanges between senators.

A. The President

The president does not always request the return of a treaty, as Pierce did, but often demands it in affirmative language. For example, Grover Cleveland, on three occasions wrote, "For the purpose of reexamination I withdraw [one or more treaties]." ${ }^{143}$ This fact, while not conclusive, suggests that at least some presidents did not feel the need to phrase their desire for the return of treaties in the form of a request, which might imply the potential for refusal, but instead in the form of a demand, which requires compliance. ${ }^{14}$

However, there might be good reason for making a request rather than a demand. The president certainly has an interest in promoting and preserving comity between his office and the Senate. He often must rely on the cooperation of the legislature to perform his duties and achieve his goals. ${ }^{145}$ The fact that Pierce made a request does not signal that he did so because he thought the Senate's consent was necessary. It is equally plausible that Pierce knew he had the power of unilateral withdrawal, but wanted to maintain a working relationship with the Senate. Especially in a regime of separated powers, a request normally would provoke a better response than would an order. With the majority of presidents assertively demanding the return of treaties, and only a few requesting their return, ${ }^{146}$ quite possibly for strategic reasons, the presidential rhetoric seems to support the unilateral power of withdrawal.

14325 Sen Exec J 7,47 (1885); James D. Richardson, 9 A Compilation of the Messages and Papers of the Presidents, 1789-1908 393 (Bureau Natl Lit \& Art 1908).

144 Other presidents using assertive language include: Arthur, 24 Sen Exec J 474 (1885) ("I now address you in order to recall") (quoting President Arthur); McKinley, 32 Sen Exec J 140 (1899) ("I withdraw") (quoting President McKinley); Theodore Roosevelt, 34 Sen Exec J 58 (1902) (same) (quoting President Theodore Roosevelt); Franklin Roosevelt, 75 Sen Exec J 87 (1934) (same) (quoting President Franklin Roosevelt); Truman, Withdrawal of Certain Treaties: Message from the President, 98 Cong Rec S 9182-83 (July 3, 1952) (message of President Truman) ("I desire to withdraw"); Eisenhower, Withdrawal of a Treaty: Message from the President, 103 Cong Rec S 12403 (July 23, 1957) (same) (message of President Eisenhower); and Nixon, 112 Sen Exec J 74-75 (1970) (same) (quoting President Nixon).

145 See, for example, US Const Art II, $\S 2, \mathrm{cl} 2$ (assigning certain powers to the President to be exercised "by and with the Advice and Consent of the Senate").

146 Presidents requesting the return of treaties include: Wilson, 52 Sen Exec J 792 (1918) ("I request the Senate to return") (quoting President Wilson); 55 Sen Exec J 83 (1920) ("I beg to request that this treaty be returned") (quoting President Wilson); and Franklin Roosevelt, 75 Sen Exec J 509 (1934) ("the return of [the treaty] I now request") (quoting President Franklin Roosevelt); Relations between the United States and Turkey, 78 Cong Rec S 628 (Jan 15, 1934) (message of President Franklin Roosevelt) ("I, therefore, request the return"). 


\section{B. The Senate}

The Senate always responds to a presidential message requesting the return of a treaty with an order or resolution. ${ }^{147}$ Historically, the structure of the response consistently conforms to this model: "Ordered [or Resolved], that the Secretary of the Senate be directed to return to the President of the United States, in compliance with his request, the following treaties." ${ }^{\text {148 }}$ The fact that the Senate always answers the President's message with an order returning the treaty might suggest that the response constitutes a grant of consent. From this view it follows that the Senate must give its consent, that the President must obtain it, and that he therefore lacks the power to withdraw a treaty unilaterally. ${ }^{149}$ However, the language of the Senate's responses and historical practice suggests that the Senate's response more plausibly fulfills an internal procedural requirement rather than a substantive bestowal of permission.

First, the language used by the Senate suggests that the order or resolution is procedural. The Senate addresses the Secretary of the Senate, and directs that officer to perform a duty-to return a treaty to the President. The language never goes beyond this. ${ }^{130}$ The absence of a phrase such as "the Senate permits," may indicate that the Senate

147 See S Rep No 106-71 at 145 (cited in note 3) ("The normal practice for returning treaties has been for the [Foreign Relations]' committee to report out, and for the Senate to adopt, a Senate resolution directing the Secretary of the Senate to return a particular treaty or treaties to the President.").

148 See note 150 . While the Senate's phrasing varies slightly, the overwhelming majority of orders and resolutions returning treaties contain the elements found in this model.

149 See notes $3,61-63,87,142$.

150 See, for example, 24 Sen Exec J 8 (1885) ("the Secretary be directed to return"); 24 Sen Exec J 474 (1885) (same); 25 Sen Exec J 47 (1885) (same); 28 Sen Exec J 410 (1893) (same); 32 Sen Exec J 140 (1899) ("Ordered, That the Secretary of the Senate return"); 34 Sen Exec J 103 (1903) ("the Secretary return"); 52 Sen Exec J 792 (1918) ("the Secretary of the Senate be directed to return"); 76 Sen Exec J 493 (1934) (same); 87 Sen Exec J 19 (1945) (same); 89 Sen Exec J 410 (1949) ("the Secretary of the Senate be, and is hereby, directed to return"); Return to the President of a Treaty and Protocol, 82d Cong, 1st Sess, in 97 Cong Rec 13237 (Oct 16, 1951) (same); Order to Return to the President the Treaty of Friendship, Commerce, and Navigation between the United States and Columbia, 83rd Cong, 1st Sess, in 99 Cong Rec 7675 (June 30, 1953) ("the Secretary of the Senate be directed to return"); Return to the President of Convention with Canada on Great Lakes Fisheries, 84th Cong, 1st Sess, in 101 Cong Rec 1379 (Feb 9, 1955) ("the Secretary of the Senate is directed to return"); Treaty of Friendship, Commerce, and Navigation between the United States of America and the Republic of Haiti: Return of Treaty to the President, 85th Cong, 1st Sess, in 103 Cong Rec 14013 (Aug 8, 1957) ("the Secretary of the Senate be, and is hereby, directed to return"); Return of Certain Treaties to the President, 85th Cong, 2d Sess, in 104 Cong Rec 11672 (June 19, 1958) (same); Withdrawal of Culture Convention with Brazil, 87th Cong, 2d Sess, in 108 Cong Rec 9448 (May 29, 1962) ("the Secretary of the Senate is directed to return"); Request by President for Withdrawal of Treaties from the Senate, 88th Cong, 2d Sess, in 110 Cong Rec 16091 (July 8, 1964) ("the Secretary of the Senate be, and is hereby, directed to return"); 112 Sen Exec J 106 (1970) ("the Secretary of the Senate is directed to return"); 142 Sen Exec J 100 (2000) (same); 89 Sen Exec J 410 (1949) ("the Secretary of the Senate be, and is hereby, directed to return"). 
does not believe that it has the power to refuse the President. ${ }^{151} \mathrm{Sec}$ ond, an internal procedural rule ${ }^{152}$ requires that a Senate order accompany the release of any executive records. ${ }^{153}$ The Secretary, by Senate rule, must have Senate authorization to return a treaty to the President. Thus, if the Senate grants permission to anyone, it is to the Secretary of the Senate, and not to the President of the United States. Third, the statements of senators themselves suggest an order or resolution responding to the President serves procedural, not substantive, purposes. For example, in 1964, responding to a presidential message withdrawing several treaties, Senator Humphrey stated, "I find that a resolution of the Senate is necessary to instruct the Secretary of the Senate to make a return of these treaties to the President." ${ }^{154}$ Finally, an entry in the Senate Executive Journal denotes the Secretary's compliance with an order of return: "Pursuant to the provisions of the orders entered on yesterday, the Secretary of the Senate this day returned to the President of the United States [the requested treaties]." "ss This evidence strongly suggests that the Senate's response to the President, by order or resolution, serves to satisfy internal procedural requirements, rather than to grant permission or consent.

Furthermore, the fact that the Senate has never refused to return a treaty to the President weighs heavily in favor of presidential unilateral withdrawal power. From Pierce ${ }^{156}$ to Clinton, ${ }^{157}$ the Senate has always complied with the President's wishes. ${ }^{158}$ And the method of compliance, at least since the Wilson administration, has been that of unanimous consent agreement. The Senate uses such agreements to

151 See note 150.

152 The Constitution provides: "Each House may determine the Rules of its Proceedings." US Const Art I, \$ 5, cl 2.

153 See Rule XXXII, S Doc No 106-15 at 41 (cited in note 34):

[N]o further extract from the Executive Journal shall be furnished by the Secretary, except by special order of the Senate; and no paper, except original treaties transmitted to the Senate by the President of the United States, and finally acted upon by the Senate, shall be delivered from the office of the Secretary without an order of the Senate for that purpose.

Executive records are those that involve both the Senate and the President together such as treaties and nominations.

154110 Cong Rec 16091 (statement of Senator Humphrey) (cited in note 150). In 1947, Senator Vandenberg made a nearly identical statement in response to a message from President Truman. 93 Cong Rec S 3583 (statement of Senator Vandenburg) (cited in note 52) ("I find that a resolution of the Senate is necessary to instruct the Secretary of the Senate to return these ancient treaties to the President.").

15575 Sen Exec J 90-91 (1934).

156 See text accompanying note 139.

157 On March 9, 2000, the Senate proposed, and on October 12, 2000, agreed to, a resolution returning seventeen treaties to President Clinton. See S Res 267, 106th Cong, 2d Sess, in 146 Cong Rec S 1423-24 (March 9, 2000); id at S 10499 (Oct 12, 2000).

158 See Glennon, Constitutional Diplomacy at 174 n 60 (cited in note 3) ("No instance has been identified in which an executive request for the return of a treaty has been rejected."). 
expedite business by circumventing normal procedural rules. ${ }^{159} \mathrm{~A}$ single objection can block a unanimous consent agreement. ${ }^{160}$ However, notably, records show that no senator has ever registered an objection to a unanimous consent agreement returning a treaty to the President. ${ }^{161}$ For example, in 1951, after reserving the right to object and asking for clarification, Senator Saltonstall engaged Senator Connally in the following discourse regarding President Truman's request for the return of a consular convention with Great Britain:

Mr. Connally. The statement I made was to the effect that the President had sent to the Senate a convention and protocol. Now he wants it returned so that he can send a different one.

Mr. Saltonstall. All that we would be doing would be to send the convention and protocol back to the President of the United States?

Mr. Connally. That is correct.

Mr. Saltonstall. There is nothing for us to consider, therefore, except to follow the President's request and send back to him a certain convention and protocol.

Mr. Connally. That is correct.

Mr. Saltonstall. I have no objection. ${ }^{162}$

This dialogue not only demonstrates willingness of senators to agree to unanimous consent agreements returning treaties, but also implies that the Senate cannot, in fact, refuse the President - "[t]here is nothing ... to consider, therefore, except to follow the President's request." ${ }^{163}$ However, this example represents one of the few instances where any discussion occurred. In the vast majority of cases, following the reading of the resolution or order, the senators unanimously consent with no debate. Therefore, the response of the Senate appears to satisfy procedural concerns, and the uniformity with which senators agree to these responses, returning treaties to the President, supports the latter's claim to the power of unilateral withdrawal.

159 Michael D. Wormser, ed, Congressional Quarterly's Guide to Congress 428 (Cong Q 3d ed 1982) ("In practice, unanimous consent agreements are widely used to expedite business.").

160 See id ("[A] single objection blocks a unanimous consent request.").

161 On two occasions senators reserved the right to object, inquired as to what the Senate was agreeing to do, and upon being told that the President simply wanted a treaty returned and the Senate was simply complying, immediately agreed to the order or resolution. See 97 Cong Rec S 13237 (cited in note 150) (Senator Saltonstall asking Senator Connally to give the general background of the resolution of return); 99 Cong Rec S 7675 (cited in note 150) (Senator Gore asking Senator Wiley to explain the order of return). In both instances, the inquiries appear to serve clarification purposes only.

16297 Cong Rec S 13237 (cited in note 150).

163 Id. 


\section{Senator Pittman's Statement}

On January 12, 1934, President Franklin Roosevelt sent a message to the Senate stating, "Due to changed conditions ... I withdraw from the Senate the treaty to regulate the general relations between the United States and Turkey." ${ }^{\text {,164 }}$ After its reading before the Senate, Senator Pittman made the only comment before the adoption of the necessary order of return. He declared, "I take it that the withdrawal is simply notice to the Senate that the President has constitutional authority to withdraw it and does withdraw it. I ask unanimous consent that the Senate recognize the withdrawal of the treaty by the President." ${ }^{165}$ This explicit statement assessing the President's authority strongly supports the theory of a unilateral power of withdrawal. ${ }^{160}$ Unaccompanied by any debate, critique, or statements to the contrary, the Senate appeared to adopt, or at the very least acquiesce in, Senator Pittman's view.

However, this conclusion might be countered with reference to a second message from Roosevelt and a second response from the Senate transacted on the very same day. The President also wrote, "Inasmuch as the ... parties to [a multi-lateral aviation treaty] have adopted a number of amendments ... I, therefore, request the return of the convention. ${ }^{\prime 167}$ The Senate considered this message prior to that withdrawing the treaty governing relations with Turkey and, following Senator Pittman's request for unanimous consent, agreed to an order "[t]hat the said treaty be returned to the President of the United States." ${ }^{168}$ Differences in the President's language, the Senate's order, and the Senator's statements, or lack thereof, might suggest some distinction exists between the two transactions. ${ }^{170}$ In fact, the Senate had voted on the treaty governing relations with Turkey and failed to achieve the required two-thirds majority, ${ }^{111}$ whereas the aviation treaty

16478 Cong Rec $S 628$ (cited in note 146).

165 Id (statement of Senator Pittman). See also Green Haywood Hackworth, 5 Digest of International Law $\& 147$ at 66 (1943) (citing solely Senator Pittman's statement in the section on the withdrawal of treaties from the Senate by the President).

166 It is worth noting that Senator Pittman's statement precedes the Supreme Court's decision in Curtiss-Wright, 299 US 304 (1936), which is often cited in support of executive authority in the realm of foreign affairs.

16778 Cong Rec 628 (cited in note 146); 75 Sen Exec J at 86 (cited in note 144).

$16875 \mathrm{Sen}$ Exec $\mathrm{J}$ at 87 (cited in note 144).

169 Id ("Ordered, That the Senate recognize the withdrawal of the said treaty by the President of the United States.").

170 Furthermore, the fact that Roosevelt used two separate messages to achieve the return of two treaties, as opposed to one message asking for both, which other presidents had done previously, might hint at some distinction.

171 The Senate voted on January 18,1927 , resulting in fifty senators in favor of the treaty, and thirty-four against. 65 Sen Exec J 338-39 (1927). For a historical discussion of the Senate's rejection of the treaty, see Roger R. Trask, The United States Response to Turkish Nationalism 
had yet to receive a vote. Accordingly, the most compelling argument for limiting Senator Pittman's view is that it applies strictly to treaties that the Senate voted on but did not achieve the requisite majority. This constitutes the narrow story of Senator Pittman's statement.

The broad story, applying Senator Pittman's view to the withdrawal of all treaties, previously voted on or not, might be preserved by certain assumptions. First, quite possibly Roosevelt considered the treaties in separate messages because he cites different reasons for their withdrawal. Or, just as plausibly, he simply wrote one message before lunch and the other after. Haste and carelessness provide a third possibility. On the other side, the differing responses from the Senate might relate directly to the differing messages from the President. Quite possibly the Senate simply responded to the particular language of the President. Or, as with Roosevelt, haste and carelessness might also explain the distinctions. Whether or not any of these assumptions are compelling, in cases where the Senate has voted on a treaty and failed to achieve a two-thirds majority, as with the CTBT that the Bush Administration desires to withdraw, not only the broad story, but also the narrow story of Senator Pittman's statement, supports the President's authority to withdraw a treaty unilaterally. In other words, at the very least, this statement substantiates presidential power to withdraw rejected treaties without Senate consent.

\section{INTERNATIONAL LAW: THE IMPLICATIONS OF ARTICLE 18}

Thus far, textual, structural, functional, and historical arguments all suggest that the President possesses power to withdraw treaties from the Senate unilaterally. But should any additional support be necessary, Article 18 provides the icing on the cake. As stated above, under Article 18, after a nation signs a treaty it must refrain from acts that would defeat the object and purpose of the treaty. ${ }^{12}$ For example, under the CTBT, the Article 18 obligation would prohibit testing a nuclear weapon. ${ }^{173}$ This obligation continues until the nation ratifies the treaty, or makes its intention clear not to become a party. Senate consideration of a treaty occurs after signature, and before ratification. Therefore, Article 18 binds the U.S. during this period. ${ }^{174}$

and Reform, 1914-1939 37-47 (Minnesota 1971).

172 For background on the discussion in this section, see Part I.B above.

173 See Restatement (Third) of Foreign Relations Law at $\S 312$, comment i ("Testing a weapon in contravention of a clause prohibiting such a test might violate the purpose of the agreement, since the consequences of the test might be irreversible.").

174 However, Article 18 also applies during the period between signature and submission to the Senate. Therefore, an analogous problem would also arise if the President signs a treaty to which he knows the Senate will not consent, but refuses to submit for consideration, while at the same time arguing that Article 18 binds the United States to avoid acts that would defeat the object and purpose of the treaty. See Bolton, Unsign That Treaty, Wash Post at A21 (cited in note 
Although a president who signs and submits a treaty would presumably prefer to act consistently with it, he might later change his mind; or, a subsequent president might disagree with the treaty. In both cases, the President would want to remove the Article 18 obligation. For example, President Bush might want to test a nuclear weapon, in contravention of the CTBT. To avoid violating Article 18, he would first need to remove the obligation. Accordingly, the President must make clear the United States's intention not to become a party to the treaty. Withdrawing the treaty from the Senate and "unsigning" it constitutes the best way to achieve this goal.

However, a problem arises if the President asks for the return of the treaty, but the Senate denies his request. In this case, it appears the President cannot "un-sign" the treaty. Perhaps he might otherwise make clear the intention not to ratify the treaty by simply making an announcement to that effect. ${ }^{175}$ But this view presents some difficulties. Only the formal act of signing a treaty invokes the Article 18 obligation. It follows that negating the obligation might require a similarly formal act. ${ }^{776}$ An announcement, especially when the Senate has refused to return the treaty, seems inadequate. Similarly, a presidential declaration that he will not ratify the treaty coupled with the Senate's refusal to return it creates ambiguity. On the one hand, the President suggests the U.S. will not be bound, while on the other, the Senate suggests the opposite. ${ }^{1 m}$ Resolving this ambiguity demands more than a presidential statement. For the purposes of formality and clarity, removing the Article 18 obligation requires the removal of the treaty from the Senate. Therefore, the Senate's refusal to return a treaty maintains the Article 18 obligation.

This problem arises in several situations. During consideration of a treaty, the Senate may or may not vote on consenting to the treaty, ${ }^{135}$

12) (criticizing President Clinton's "last-minute decision" to sign the treaty creating an International Criminal Court because he did not intend to submit it to the Senate but instead invoked Article 18).

175 Professor Glennon seems to suggest that a declaration by the President would remove the obligation. See Glennon, Constitutional Diplomacy at 174 (cited in note 3) ("[I]n the case of a bilateral treaty, the President might simply notify the other signatory that the United States does not intend to pursue ratification.").

176 See Aust, Modern Treaty Law at 95 (cited in note 29) (suggesting a signatory might withdraw its consent to be bound "given certain circumstances"). This is not to suggest that the President has to shred or burn the actual treaty document, but only that an announcement is not enough when the Senate has not returned the treaty to the President.

17 While the fact that the President serves as the "sole organ" in foreign relations suggests his view trumps all, see text accompanying notes $99-100,132$, the Senate's constitutional role in the treaty process weighs against his ability to resolve all ambiguity with a simple statement.

178 Consenting to a treaty requires a two-thirds vote of the senators present. US Const Art II, $\$ 2, \mathrm{cl} 2$. 
and may or may not vote on a resolution of return. ${ }^{139}$ The Senate's actions, absent the power of the President to withdraw unilaterally, determine whether the treaty remains in the Senate or is returned to the President. The chart below presents the possible scenarios.

\begin{tabular}{|c|c|c|c|}
\hline \multicolumn{4}{|c|}{ POSSIBLE SCENARIOS } \\
\hline \multicolumn{2}{|c|}{ Senate Actions } & \multicolumn{2}{|c|}{ Result of Senate Actions } \\
\hline $\begin{array}{c}\text { Vote on Advice } \\
\text { and Consent to } \\
\text { Treaty }\end{array}$ & $\begin{array}{c}\text { Vote on } \\
\text { Resolution } \\
\text { of Return }\end{array}$ & $\begin{array}{l}\text { Subsequent } \\
\text { Location } \\
\text { of Treaty }\end{array}$ & $\begin{array}{c}\text { Article } 18 \\
\text { Obligation } \\
\text { Problem }\end{array}$ \\
\hline $\begin{array}{l}\text { 1. Greater than } \\
\text { or equal to } \\
2 / 3 \text { in favor }\end{array}$ & Not applicable & $\begin{array}{l}\text { Returned to } \\
\text { President }\end{array}$ & No \\
\hline $\begin{array}{l}\text { 2. Less than } 2 / 3 \\
\text { in favor }\end{array}$ & $\begin{array}{l}\text { Greater than } 1 / 2 \\
\text { in favor }\end{array}$ & $\begin{array}{l}\text { Returned to } \\
\text { President }\end{array}$ & No \\
\hline 3. No vote & $\begin{array}{l}\text { Greater than } 1 / 2 \\
\text { in favor }\end{array}$ & $\begin{array}{l}\text { Returned to } \\
\text { President }\end{array}$ & No \\
\hline $\begin{array}{l}\text { 4. Less than } 2 / 3 \\
\text { in favor }\end{array}$ & $\begin{array}{l}\text { Less than } 1 / 2 \\
\text { in favor }\end{array}$ & Remains in Senate & Yes \\
\hline $\begin{array}{l}\text { 5. Less than } 2 / 3 \\
\text { in favor }\end{array}$ & $\begin{array}{l}\text { Less than } 1 / 3 \text { in } \\
\text { favor (more } \\
\text { than } 2 / 3 \text { in favor } \\
\text { of retaining) }\end{array}$ & Remains in Senate & Yes \\
\hline $\begin{array}{l}\text { 6. Less than } 2 / 3 \\
\text { in favor }\end{array}$ & No vote & Remains in Senate & Yes \\
\hline 7. No vote & $\begin{array}{l}\text { Less than } 1 / 2 \\
\text { in favor }\end{array}$ & Remains in Senate & Yes \\
\hline 8. No vote & $\begin{array}{l}\text { Less than } 1 / 3 \text { in } \\
\text { favor (more than } \\
2 / 3 \text { in favor of } \\
\text { retaining) }\end{array}$ & Remains in Senate & Yes \\
\hline 9. No vote & No vote & Remains in Senate & Yes \\
\hline
\end{tabular}

In six of the nine situations, the actions of the Senate create an Article 18 problem. The President desires to remove the Article 18 obligation, but because the treaty remains in the Senate, he is prevented from doing so.

Furthermore, by acting to maintain the Article 18 obligation, the Senate circumvents the Treaty Clause. ${ }^{180}$ Where the Senate (1) fails to text.

179 Adopting a resolution of return requires a majority vote. See note 50 and accompanying

180 US Const Art II, § 2, cl 2 ("He [the President] shall have power, by and with the Advice and Consent of the Senate, to make Treaties, provided two thirds of the Senators present concur."). See Glennon, Constitutional Diplomacy at $174 \mathrm{n} 61$ (cited in note 3) ("The argument might be made that to observe the terms of a treaty until the defeat of a 'resolution of return' would effectively change the fraction of the Senate required for approval from two-thirds to one-half."). See also Dangerfield, In Defense of the Senate at 213 (cited in note 31) ("Since twothirds is required to approve a treaty and a simple majority is required for other actions, it is possible that a deadlock may result in the handling of a treaty. If a treaty fails to receive the two- 
achieve a two-thirds vote in favor of consenting to the treaty, or fails to vote on the treaty; and (2) fails to achieve a majority vote in favor of adopting a resolution of return, or fails to vote on the resolution; the U.S. remains obligated to uphold Article 18. This creates a commitment to refrain from acts that would defeat the object and purpose of the treaty while the treaty remains unratified. ${ }^{1.1}$

The solution to this problem lies with the unilateral power of the President to withdraw treaties from the Senate. Such authority would allow the President to withdraw a signed treaty from the Senate in order to "un-sign" it and make clear the United States's intention not to ratify. By withdrawing and "un-signing" the treaty, the President makes the U.S. position formal and unambiguous, thus removing the Article 18 obligation attendant to signature. The international law implications of Article 18 provide additional support for the President's power to withdraw signed treaties from the Senate unilaterally.

\section{CONCLUSION}

The issue of unilateral treaty withdrawal is important for the constitutional allocation of treaty-making powers, and for addressing the implications of the interim obligations of a signatory to a treaty under Article 18. President Bush aborted his plan to withdraw the Comprehensive Test Ban Treaty from the Senate unilaterally after State Department legal advisors said he did not have the power to do so. This Comment argues that the President of the United States does, and should, have such a power from both a constitutional and historical perspective. Moreover, the international law implications also support the President's power to withdraw treaties from the Senate unilaterally. This conclusion suggests, for example, that President Bush has the authority to withdraw the CTBT, even if the Senate rejects his request for its return. While presidents should continue to request the return of treaties for the purpose of comity, on the rare occasion that the Senate refuses, unilateral withdrawal exists as a final option.

\footnotetext{
thirds, but does receive a majority, it cannot be approved but on the other hand the majority may refuse to return the treaty to the President.").

181 One might argue that when two-thirds of the Senate defeat a resolution of return, the Treaty Clause is not circumvented. See scenarios five and eight in the chart. However, a twothirds majority of senators agreeing to retain a treaty in the Senate does not equate to two-thirds consenting to the treaty. The constitutional requirements must be met.
} 


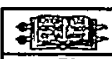

